\title{
A TWO-POINT STUDY OF PARENTAL PERCEPTION OF DIGITAL TECHNOLOGY IN CROATIAN PRESCHOOL CHILDREN
}

\author{
MARINA KOTRLA TOPIĆ ${ }^{1}$, MARINA PERKOVIĆ KOVAČEVIĆ ${ }^{2}$, IVANA DUVNJAK ${ }^{3}$ \\ ${ }^{1}$ Institut društvenih znanosti Ivo Pilar - Centar Osijek, contact: marina.kotrla.topic@pilar.hr \\ ${ }^{2}$ Kliničko-bolnički centar Osijek, ${ }^{3}$ Filozofski fakultet Osijek
}

Received: 03.04.2019.

Original scientific paper

Accepted: 22.09.2019.

UDK 004-053.4(497.5):159.937-055.52

https://doi.org/10.31299/hrri.55.2.1

\begin{abstract}
To get a better understanding of the parental perception of digital devices used by preschool children in Croatia, as well as their expectations and mediation strategies, we report the findings from a qualitative study with two measurement points. At the first point, five families with children aged 6 to 7 were interviewed at their homes, where they provided information on how their children engage with new technologies, how such technologies are perceived by different family members and how parents manage their children's use of digital technology. A year and a half later, the same families were interviewed again, in a similar manner, focusing on the changes which happened in that period, as reported by the parents. Results show that parents find digital technology important and beneficial for children's cognitive and emotional development, but they fear possible negative consequences of its use. Most often, they use restrictive mediation. A year and a half later, parents also express the need for more educational support when it comes to mediating their children's interaction with digital technology.
\end{abstract}

Key words: digital technology, parental perception, mediation strategies, preschool age

\section{INTRODUCTION}

Nowadays, young children are surrounded with digital technology (DT) from the moment they are born. In general, technology is defined as the use of tools and methods intended to create and produce (Vittrup, Snider, Rose, \& Rippy, 2016), while DT pertains to various desktops, such as computers, as well as mobile technologies, laptops and digital toys (O'Hara, 2011), and also to software.

Digital devices are becoming more easily available and when this ease of access is paired with extensive marketing, parents are often pressured to include them in their family lives. Rideout (2017) states that the prevalence of mobile devices usage increased from $38 \%$ in 2011 to $72 \%$ in 2013 , and in 2017 , that usage increased to $84 \%$ (usage of some type of a mobile device in the United States). Genc's (2014) qualitative study shows that DT is present in children's lives and that families own many various digital devices.
Such accelerated increase in the use of digital devices in families is not accompanied with any type of formal education available to parents on possible positive and negative effects DT may have on children's development and education. Today's technology was not part of many generations of parents' upbringing (Plowman, McPake, \& Stephen, 2010). Furthermore, researchers in this field still debate on the extent to which young children's interaction with DT can potentially be harmful (e.g. Vandewater et al., 2007) or beneficial (e.g. Burke \& Marsh, 2013). DT use has been linked to the amount and quality of sleep, attention problems, depression, anxiety, low self-esteem and subjective well-being (Galpin \& Taylor, 2018). On the other hand, DT use at preschool age can be linked to better school readiness (Li, Atkins, \& Stanton, 2016) and it also presents opportunities for learning, creating, collaboration, communication and promoting healthy behaviors (Blum-Ross \& Livingstone, 2016). 
Until recently, there was a lack of research in the preschool age span, compared to the research conducted with school-aged children and adolescents (Ólafsson, Livingstone, \& Haddon, 2013). Also, there was a lack of studies focusing on digital practices in home environment, especially those considering the entire family instead of just individuals. More than two decades ago, Goodman (1983) called for using families instead of individuals as the primary unit of analyses in family-media research. She called for changes in how we view the role of media in families, and although at the time she referred to television, her call is even more important nowadays when family lives are becoming exceedingly saturated with digital technology. To better understand the rich and complex interplay between family members and digital devices, we need to move from quantitative studies that provide data on usage level and on how individuals use media in a household, and turn to more elaborate studies that can provide better comprehension of how a preschool child, as a member of a certain family, interacts with DT and how his parents manage such interaction (Gentile \& Walsh, 2002). In this regard, our research questions and methods are influenced by the family systems perspective.

Prior research shows that parental modelling of digital technology use might influence the way children use digital devices (social cognitive model; Bandura, 1977) (Nikken \& Schols, 2015). In this context, it is important to consider how parental perception of DT can be related to children's use of DT at home. Existing research points to a significant relationship between parental perception of DT and children's screen time, with studies linking negative parental attitudes with less screen time (Nathanson, Eveland, Park, \& Paul, 2002; Padilla-Walker, 2006), and positive parental attitudes with more screen time (Vaala \& Hornik, 2014). Some studies report no link between the negative parental perception and children's screen time for preschool children (Sanders, Parent, Forehand, Sullivan, \& Jones, 2016).

Besides being the role models for observational learning, parents act as mediators of DT use. Parental mediation refers to diverse practices for managing and regulating children's experiences with DT (Livingstone, Mascheroni, Dreier, Chaudron, \& Lagae, 2015). Prior research shows that there are differences in mediation strategies across countries (Kalmus \& Roosalu, 2012). Helsper, Kalmus, Hasebrink, Sagvari, \& de Haan, (2013) made a classification of European countries according to the prevailing type of parental mediation, but there are no data for Croatia available.

In Croatia, in 2016 , there were $77 \%$ of households with a computer and/or Internet access (CBS, 2018). On the other hand, data from the same year show that $10.7 \%$ of families with children were in severe material deprivation (Eurostat, 2018). Therefore, it is difficult to give a clear account of the possible digital divide in this country. We are, however, witnessing a generational digital divide between preschool children and their parents, with initial research showing generally negative attitudes towards the use of computers by children aged two or younger, but generally positive attitudes towards the use of computers by children aged 6 (Mikelić Preradović, Lešin \& Šagud, 2016).

In this research we are interested in how Croatian parents view digital technology and how they manage their children's use of DT, how they create and adapt the rules and how they struggle with their children's media consumption and changes in family life circumstances. Using a twopoint measurement design enables us to get a better understanding of parental perception of DT and parents' mediation strategies, and how these adapt to changes in family circumstances. The second study was done a year and a half after the first one. This specific time frame for the second study was chosen because during that period, four target children who were in kindergarten at the time of the first study started primary school.

\section{METHOD}

The research questions we want to address are how parents of young children in Croatia perceive digital technology, how they manage their children's use of such technology, and how and why their perception evolves in a one-and-a-half-year period. DT refers to television, desktop and laptop computers, tablets, smartphones, gaming consoles and other gaming devices. Television was not initially planned to be included in the research, but many of the parents mentioned that they used their TVs to access the Internet or watch movies and cartoons played on 
Table 1. Some characteristics of the families in the sample (target child is marked in bold, and the age indicates the age at the time of the first study)

\begin{tabular}{|c|c|c|c|c|c|}
\hline Family code & Sex & Age & Max level of education & Rate of DT use by target child & Digital device ownership \\
\hline \multirow[t]{5}{*}{ HR1 } & $\mathrm{F}$ & 36 & Tertiary & \multirow[t]{5}{*}{ Medium user } & \multirow[t]{5}{*}{ TV, two smartphones, laptop } \\
\hline & $\mathrm{M}$ & 36 & Tertiary & & \\
\hline & $\mathrm{M}$ & 6 & Kindergarten & & \\
\hline & $\mathrm{M}$ & 4 & Kindergarten & & \\
\hline & $\mathrm{M}$ & 1 & Kindergarten & & \\
\hline \multirow[t]{4}{*}{ HR2 } & $\mathrm{M}$ & 31 & Secondary & \multirow[t]{4}{*}{ Medium user } & \multirow{4}{*}{$\begin{array}{l}\mathrm{TV} \text {, tablet, desktop computer, Sony } \\
\text { play station, three smartphones (one of } \\
\text { which has no SIM card) }\end{array}$} \\
\hline & $\mathrm{F}$ & 34 & Tertiary & & \\
\hline & $\mathrm{F}$ & 6 & Kindergarten & & \\
\hline & $\mathrm{F}$ & 2 & Kindergarten & & \\
\hline \multirow[t]{3}{*}{ HR3 } & $\mathrm{M}$ & 40 & Secondary & \multirow[t]{3}{*}{ High user } & \multirow{3}{*}{$\begin{array}{l}\text { TV, two desktop computers, two } \\
\text { smartphones, tablet }\end{array}$} \\
\hline & $\mathrm{F}$ & 38 & Secondary & & \\
\hline & $\mathrm{M}$ & 6 & Kindergarten & & \\
\hline \multirow[t]{2}{*}{ HR4 } & $\mathrm{M}$ & 36 & Secondary & \multirow[t]{2}{*}{ Low user } & \multirow[t]{2}{*}{ TV, laptop, smartphone } \\
\hline & $\mathrm{F}$ & 6 & Kindergarten & & \\
\hline \multirow[t]{4}{*}{ HR5 } & $\mathrm{N}$ & 43 & University & \multirow[t]{4}{*}{ Medium user } & \multirow{4}{*}{$\begin{array}{l}\text { TV, computer, Nintendo Wii, tablet, } \\
\text { four smartphones (one of which has no } \\
\text { SIM card) }\end{array}$} \\
\hline & $\mathrm{F}$ & 41 & University & & \\
\hline & $\mathrm{F}$ & 7 & 2nd Primary & & \\
\hline & $\mathrm{F}$ & 12 & 6nd Primary & & \\
\hline
\end{tabular}

a computer, which points to a new aspect of television use compared to the traditional one.

The data reported here are a part of a wider research conducted in collaboration with JRC of the European Commission ${ }^{1}$ (Kotrla Topić \& Perković Kovačević, 2017). Data were gathered using interviews and observations.

\section{Participants}

The study included five families with at least one child aged 6 or 7 . The families were recruited through personal contacts, applying the snowball procedure. The participating families are described in Table 1.

We especially aimed to find families whose target children use digital technology at least once a week (low users), two or three times a week (medium users) and at least once a day (high users).

\section{The interview protocol}

We used a semi-structured interview as a method to collect answers to our research questions. This means that we had interview protocols prepared both for the parents and for the children, but the questions in them were used more as guidelines for conversation and not as a strict set of questions that needed to be answered in the exact order as they were presented. For example, we asked the parents if they thought of any DTs as particularly "positive" or "negative" for their children, which ones and why; how important they thought DTs were for their children, if they thought that their children's use of (online) technologies interfered in any way (positive and/or negative) with family life, if they talked to their children to try to guide how they go online or what they might do online, if there were any particular things they encouraged their children to do or explore online, etc. The children were asked age appropriate questions, such as if there were, in their opinion, any good or bad things about using the internet (or X device), what they thought about a specific device, what word would they choose if they had to choose a word to describe such a device, etc.

\section{Procedure}

In the first study, after the Ethical committees from the authors' institutions approved the research,

1 The data reported here are a part of the research project 'Young children (0-8) and digital technology', co-funded and coordinated by the Joint Research Centre of the European Commission, which looked closely at the digital engagement of young children under the age of 8 in 21 countries in Europe. The final report from this project can be accessed at https://ec.europa.eu/jrc/en/publication/eur-scientific-and-technicalresearch-reports/young-children-0-8-and-digital-technology-qualitative-study-across-europe 
potential families were contacted and interviews were scheduled. The interviews were conducted personally by the two principal researchers. They both have considerable experience in this research area, as well as in conducting research interviews. The families were told we wanted them to tell us, as openly and precisely as possible, how they e.g. managed their children's use of digital technology, regardless of their assumptions on how other families did it. They were instructed to decrease the level of socially desirable answering. During the interviews, they were constantly encouraged to be as honest and open as possible.

After the initial part, in which all the family members and both researchers introduced themselves and together went through the ice-breaking activity using a specially prepared activity book in which the children had a task of telling us about their usual daily activities, using stickers, the researchers would split up, with one doing a separate interview with the child and the other with the parent(s). The interviews were audio recorded. Interviews took place between July and October 2015. Transcribing and preliminary coding was done after each individual interview. The analysis was done based on the transcripts, using the thematic analysis approach. Thematic analysis is a method of analyzing quantitative data by identifying, analyzing, and reporting patterns (themes) within those data (Braun \& Clarke, 2006). Specifically, after the initial independent re-reading of all the transcripts, two researchers coded different topics that came up in the transcripts. They then compared the codes in search for the ones that are most important in relation to the research questions and searched for quotes from different families that held information in relation to them. Finally, they interpreted the data that were available.

In the second study, the procedure was mostly identical to the one in the first study. The interview started with remembering the last visit, and the data gathered on that occasion. Again, the interviews were audio recorded. Interviews took place from January to February 2017. Transcribing and preliminary coding was done after each individual interview. Type of thematic analysis applied was the same as in the first study.

\section{RESULTS AND DISCUSSION}

This study focuses on parental perception and mediation styles with regard to DT use by young children in home environment. Earlier studies point to parents having a low level of awareness regarding their children's use of DT, which might lead to a low level of their active engagement in that interaction (Rideout, Vandewater, \& Wartella, 2003; Vittrup, 2009; Vittrup et al., 2016). Understanding these factors can help us better understand young children's experiences with DT in a family context. Furthermore, it might help us develop better recommendations for age-appropriate screen time, which would then be presented to the parents so that they can apply them on a daily basis.

Before we consider parental perception of digital technology, we need to address the question of families' device ownership. However, in considering this matter we need to be careful because, in the case of preschool children, high levels of ownership do not equate to high levels of use (Plowman, Stevenson, Stephen, \& McPake, 2012), as this research also clearly shows. Data on ownership are presented in Table 1 .

\section{Parents 'perception of children's use of digital technology}

The first research question we wanted to explore was how parents of preschool children feel about their children's use of digital devices in home environment. Our results from both studies show what we could describe as a love-hate relationship between the parents and DT.

\section{Downsides of using DT}

In almost all of the families we visited, when asked about their perception of DT, the parents would first state they are generally not happy their children use it, but when asked to elaborate on their opinion, they had trouble specifying the reasons why.

Their biggest concern was that children might get addicted to a device or to digital content. This fear was supported by sometimes inappropriate reactions their children had when the screen time was over and a device was taken away from them. Parents reported that at those times children tended to overreact, sometimes displaying aggressive behavior - yelling, refusing to communicate and throwing toys, without any idea how to continue 
Hrvatska revija za rehabilitacijska istraživanja 2019, Vol 55, br. 2, str. 1-13

playing without the digital device - and sometimes responding with cranky, unsatisfied whining.

"I don't think there is anything positive, it just spoils your eyes and makes you addictive." (Father of a 6-year-old)

Children are also sometimes aware of this effect of DT on them:

"Too much TV and computer can make you crazy." (a 6-year-old boy)

The fear of their children developing an addiction to DT is something Croatian parents share with parents from other European countries (Chaudron et al., 2015; Plowman \& Stephen, 2003). Possible addictive nature of digital media for younger children compared to older populations is still being researched, and even for older children and adolescents there are no agreed diagnostic criteria for digital technology addiction (Poli, 2017). Studies showing that children aged 8 to 12 spend almost six hours a day using digital media (Common Sense Media, 2015) argue that the sheer amount of screen time is evidence of an addiction. Others focus more on the possible negative repercussions of digital media use, just like the parents in this study (Dumoff et al., 2017; Felt \& Robb, 2016). In fact, research supports these worries showing that higher results on Parent Report Measure of Screen Media "Addiction" in Children are related to more parental reports of conflicts with children, as well as different behavioral problems (Dumoff et al., 2017).

Parents are also worried that technology takes away children's time that would otherwise be spent outside or playing with traditional toys and other children, and they are worried about the effect this might have on them.

"They should spend more time hanging out with each other, in the street, talk to each other more, laugh more, fool around more, and not hide behind their own screen." (Mother of a 7-year-old)

In literature, this concern is referred to as "the displacement hypothesis" (Galpin \& Taylor, 2018) and its key concept is that digital media use displaces the time children would spent doing other activities. Previous research offers mixed results on this issue, showing only a mild displacement effect of digital media use (Marshall et al., 2004). Similarly, in our research, despite parental worries, what we found was not a clear distinction of traditional play and play that includes DT, as some previous research also indicates (McPake, Plowman \& Stephen, 2013; Roberts \& Foehr, 2004). Children watching Lego movies on YouTube would very often play with Lego bricks in a traditional manner. Some parents mentioned they feared a negative impact of DT on their children's eyesight and body posture. Indeed, in their early years, children go through intensive cognitive and emotional development, and their primary learning tool is play. The use of digital devices changes traditional approach to play in several ways. One of them, often mentioned in the literature, is that the use of digital devices makes children more physically passive, which might lead to problems with obesity (KFF, 2004; Marshall et al., 2004). Previous research also points to a link between digital technology use in early years and problems with attention (Swing, Gentile, Anderson, \& Walsh 2010), as well as social, cognitive and language development (McCarrick \& Li, 2007), but those concerns were never explicitly mentioned by the parents in this study.

Apart from worries related to the use of DT in general, some of the parents mentioned a possible negative effect of specific content their children consumed - namely the effect of playing aggressive games and watching violent content. In fact, two families reported such effects in their children, and previous studies support such worries (Anderson et al., 2010). Previous research clearly confirms strong associations between violent content and aggressive behavior in children (American Academy of Pediatrics, 2016), and researchers urge parents to supervise their children's interactions with digital media (Chassiakos et al., 2016).

\section{Positive sides of using DT}

As stated earlier, at both measurement points, the parents also expressed some positive views about their children's use of DT. Most of them feel that digital literacy is vital in today's modern world, and that children's interaction with digital devices at an early age is beneficial in that regard. Parents think that through interaction with DT, 
children can benefit not only from the relevant learning material, but also from the fact that they are learning it through digital media. They feel that children's interaction with digital devices enhances their digital literacy skills, which are important for their future academic and even professional success. These findings are in line with other research on parental perception of the importance of digital technology for academic achievement and professional success (Ortiz, Green \& Liam, 2011). Hatzigianni \& Margetts (2014) also showed that parents value their children's technical skills because they find them important for their future careers. Vittrup et al. (2014) showed that parents of even younger children, those aged 0 to 3 , fear that their children might fall behind if they are not exposed to digital technology.

However, when we look at the specific digital literacy skills of the children in this study, they are at a low level. Most children in the study know how to turn the device on and off, and they know how to start a game or an app or how to download it to a device from the Internet. However, they do not differentiate between being "online" and "offline", and on rare occasions when they want to look up something on the Internet, they need help from adults. By the time of the second study, as reported by the parents, children had not gained any new skills. Previous research shows that parents overestimate their children's knowledge regarding digital media (Vittrup et al., 2016).

Some parents mentioned a positive effect of digital technology on cognitive development, including intelligence. In this regard, those parents also think that digital technology aids children in the learning process, regardless of the material they need to learn, because it helps them visualize things through pictures and animations. Previous research shows that parents put great value on educational aspect of digital media (Nevski \& Siibak, 2016), and even use it to explain and justify why they let young children use digital media in the first place (Baek, Lee \& Kim, 2013). At the same time, analysis of children's activities with digital media shows that children rarely consume educational content compared to entertaining one (Baek, Lee \& Kim, 2013), and that parents rarely use digital media for the purpose of teaching children (Schlembach \& Johnson, 2014).
In a similar manner, learning a foreign language was often mentioned by the parents in this study as an activity made easier by using DT, but at the same time, none of the families in both studies used any specific apps designed for learning foreign languages. Still, while interacting with DT, children encounter written and/or spoken English. Previous studies also show that parents think technology has a positive effect on language development (Hanna, 2016). Another example of the parents' views on how DT can help their children's education is their opinion that with the help of educational cartoons children can learn about good manners, how to be a good friend and even learn about empathy - how to recognize when someone if feeling down, and how to try and help them. Indeed, previous research supports such claims (Greitemeyer, 2011).

Important positive aspect of DT, mentioned by most parents in the study, is the ease of information seeking. Whenever their children want to find out more about something that interests them, parents can easily find the information on the Internet. Those same parents often encourage their children to learn how to search for such information on their own, but at the time of the first study, most children were still in kindergarten and had limited reading and writing skills, which made it hard for them to use the Internet search engines by themselves. At the time of the second study, parents reported no changes in this respect, meaning that the children still didn't search the Internet on their own to learn something new.

\section{Parental mediation of children's use of digital technology}

The second research question we wanted to address is how parents manage their children's use of DT. Literature points to three ways in which parents can limit the amount of screen time - by setting limits regarding the amount of time spent interacting with DT, regarding the content allowed or the context in which such activities take place (Gentile \& Walsh, 2002). The content refers to different games, programs, activities or applications children are allowed to consume. Parents in the sample show both active and restrictive style of mediation when it comes to DT. Except for one family that practically uses no digital devices apart 
from television, all the other parents allow their children a certain amount of screen time, but try to have strict rules about which digital devices, when and for how long the children can use, although some children have a different view on the matter: boy)

"I play games when I want to." (a 6-year-old

The relevant literature describes two parental mediation strategies for parents of 6- to 14-year old children: enabling mediation, which is characterized by increased online opportunities, but also by risks, and restrictive mediation, with fewer online risks, which sees media use as primarily problematic (Livingstone et al., 2017). Parents in this study can be described as using restrictive mediation. Their children have restrictions regarding both time and content, but they are also exposed to fewer online risks.

As for the time and content limitations, parents in the study try to limit screen time in general, with less consideration of the content. It means that children are the ones who choose what they do during that time and what content they watch. This might be concerning because research shows numerous effects related to the content of the media consumed, which are independent of the amount of screen time (Gentile \& Walsh, 2002). But children choose from a previously defined set of activities, so parents see this method as a clever way to manage their choices without arguments. Prior research points to the fact that parents often want to reduce the screen time for their children but are uncertain how to do it (Jordan, Hersey, McDevitt \& Heitzer, 2006). Some of the parents in this study had the same problem.

There was one family in which parents primarily considered what the child was doing with less consideration about setting a strict time limit. Their explanation was that their child spends some time after kindergarten at home with his grandparents looking after him, and during that time the grandparents want to indulge him in different ways, one of which was to let him spend time using digital technology. The parents were under the impression that it is better for them to choose the content that the child can watch than to engage in continuous arguments with the grandparents and the child about the screen time. Vittrup et al. (2016) showed that $67 \%$ of parents in their sample believed it was appropriate to let children use digital media while adults do other tasks, but to the best of our knowledge, there is no specific research on situations in which parents agree that their children use digital media while being cared for by other family members in order to make it easier for those family members to complete their tasks.

What is interesting is that while all the parents try to have strict and clear rules and do their best for those rules to be obeyed, the process of setting the rules in the first place is quite spontaneous. This means that the rules change as new situations and circumstances arise, without much consideration for future practices. Some researchers suggest that the lack of parental involvement regarding their children's interaction with DT comes from their inability to control it, or their lack of time and energy, which is a direct result of the busy contemporary lifestyle (Roberts \& Foehr, 2004).

Furthermore, it is interesting that having straightforward and clear rules about the time restrictions did not, in fact, mean that children had less screen time when compared to the children in the families who had more loose rules. Important factor to consider here was how interested the child itself was in the use of different digital devices. For example, in one of the families parents described their daughter as not interested in DT at all, so they had no need to set strict the rules about its use.

All the parents, except for the father from the family with very limited number of devices try to practice active mediation through talking about the content the child can watch, giving basic instructions on what to do in specific situations to enhance safety, teaching children how to use different digital tools, etc. This is important because research shows that children's responses to digital media can be changed by parental mediation (Chakroff \& Nathanson, 2008).

\section{How did the parent's perceptions of children's DT use evolve in one year's time?}

Results from the follow-up study showed that three families obtained some new devices. To be more precise, one family got a new tablet and in two families children got SIM cards either 
for their own or their parent's old smartphones, which means that those families did not get any new devices, but rather upgraded their old ones.

Parents report no changes in their perception of DT. When asked about what DT means to their family life, parents respond it is something that helps them relax in their free time, and something that is part of family rituals - watching cartoons together with the children. Such notion is in line with the family systems perspective (Goodman, 1983) because it shows that to analyze the use of digital devices in preschool children we need to study the entire family. If it was not for the parents who use this technology together with their children in family rituals, the children themselves would have somewhat different experience with the technology. All the parents, except for one, still feel that DT is a good tool for learning new information and that it can help build stronger family connections because family members who live far away from each other can communicate more often using digital technology. The parents whose children now have smartphones, also feel that digital technology helps them in keeping in touch with their children while they are at school or going to/ from school alone. Just like at the time of the first study, parents worry that using digital technology too much might alienate the children from other activities. In relation to that, they fear the children might become addicted to certain devices and that it might affect their health, just as they thought at the time of the first study.

There were also some newly mentioned fears. One mother, from the family whose son spends quite a lot of time with his grandparents, who let him use DM for longer periods of time, had a particularly strong fear of her son meeting someone online who could eventually harm him. At the moment, he has no access to social media or chat rooms, so her fear is based on what might happen in the future. Other parents also mentioned worries regarding social networks and their possible influence on their children, although, in fact, none of the children in the study had access to social networks. But, it is clear that as children are becoming older and interact with other children outside the family, they get exposed to more potential uses of digital media, such as social networks, and the parents are not quite prepared for handling such situations. It is important to note that parents anticipate possible threats in the future, because previous studies show that parents underestimate the risk of their children being exposed to, for example, sexual or violent content, when compared to other children (Meirick, Sims, Gilchrist, \& Croucher, 2009).

One particular concern that most parents (three out of five) in the follow-up study mentioned was the lack of confidence in their own digital literacy skills and how that might affect their children's learning about DT. Some parents clearly expressed the need to get more guidance and help in managing their children's screen time and choosing the right activity for them and in some cases they mention that this insight is also a result from their deeper thinking about this topic during the first interview. Previous studies suggest that due to low level of parental technical expertise, time and communication skills, it is not reasonable to expect them to effectively guide their children's use of digital media (Livingstone, Van Couvering, \& Thumin, 2005). Therefore, researchers suggest that encouraging parents to engage in mediation of their children's digital media use should be paired with programs that enhance their own digital literacy skills as well (Rasmussen, White, King, Holiday, \& Densley, 2016).

\section{How did parents ' mediation of young children's use of DT evolve in one year's time?}

All of the parents in the follow-up study showed either active or restrictive style, or both styles of mediation when it comes to DT, just as they did a year and a half earlier. However, on a daily basis, things are a little different than before. As noted earlier, for most of the families, at the time of the first study, the rules changed as new situations and circumstances occurred, and for most of them the situation had changed because, in the meantime, the target child from the first study started school. This means that at the time of the follow-up study, some of the children were spending more time home alone than before, and that time often correlated with the use of digital devices. Parents felt they could not ban the use of devices during the time the children were home alone, because they thought that children being occupied with 
Hrvatska revija za rehabilitacijska istraživanja 2019, Vol 55, br. 2, str. 1-13

digital devices was preferable to worrying about the fact they were home alone. That is why they try to instruct their children on the devices they can use and the activities for which they can use them. According to Nikken and Jansz (2014), this type of mediation is a restrictive mediation II, in which parents restrict the content by, for example, banning certain sites or devices, but at the same time, they are more flexible with time restrictions.

\section{Limitations of the study}

There are some methodological limitations of these two studies. The studies include only families from eastern Croatia, and the sample size is small. A larger sample would allow more systematic analysis of parental mediation strategies, e.g. by age. Additionally, most parents in the sample use restrictive mediation and with a larger sample we could learn more about families with different mediation strategies. Furthermore, we would recommend multiple visits to families in order to use every following visit to further discuss certain points with parents or to gain deeper clarification of such points. Also, because it is very important to examine the long-term effects of digital technology use, we would recommend further longitudinal research with more measurement points.

\section{CONCLUSION}

More and more children are exposed to different digital devices at a very young age, and in many families, the use of such devices both by parents and by children is part of daily routine (Kucirkova, 2011). Research also shows that children go online at an increasingly younger age, and the younger they are, the more vulnerable they are to the effects of digital technology (Livingstone, Gorzig, \& Olafsson, 2011).

While most studies on parental perception of DT aim to find correlations with the amount of time children are allowed to use such technology, in these two qualitative studies, besides investigating the general positive or negative parental perception, we aimed to get a closer insight into the entire range of the specific fears and worries of Croatian parents, as well as their perceived benefits regarding their children's use of DT.
Our findings show that Croatian parents have both positive and negative feelings about DT, which is similar to findings in other countries (Genc, 2014; Livingstone et al., 2015; Tokes, 2016) and in earlier studies conducted in Croatia (Mikelić Preradović, Lešin, \& Šagud, 2016). They worry about their children getting addicted to DT or neglecting other areas of interest because of DT. They are also worried about the negative effect of aggressive content that children might get in contact with. On the other hand, parents feel that interaction with DT enhances their children's digital literacy skills and helps them with the process of learning and information seeking.

As for the ways of managing the children's use of DT, most parents in this research show restricted mediation strategies. It is this finding that might help us position Croatia in future studies of differences in parental mediation across countries, which Livingstone et al. (2015) cite as one of the two main themes discussed in the academic literature. Rules are often changed when new situations occur, without a specific plan for the future, which was especially evident in the follow-up study, when most children started school. Due to the trend of higher use of DT in families, recommendations found in the literature on the subject include either restrictive mediation (media time limits) or active mediation (co-viewing media) (Blum-Ross \& Livingstone, 2016).

The follow-up study revealed growing parental concern about how to teach the children how to use DT for more than just entertainment. We can conclude that parents have varying levels of DT usage, and hence different levels of knowledge about DT. As experts, we have an obligation to educate parents regarding potential benefits and developmentally appropriate content and activities for children's use, as well as regarding different mediations strategies. We also have an obligation to work on enhancing digital literacy skills of the parents, in order to enable them to apply those recommendations more efficiently. 
Marina Kotrla Topić, Marina Perković Kovačević, Ivana Duvnjak: A two-point study of parental perception of digital technology in Croatian...

\section{REFERENCES}

American Academy of Pediatrics, Council on Communications and Media (2016). Virtual violence statement. Pediatrics, 138(1), 2016-1298.

Anderson, C. A., Shibuya, A., Ihori, N., Swing, E. L., Bushman, B. J., Sakamoto, A., Rothstein, H. R., \& Saleem, M. (2010). Violent video game effects on aggression, empathy, and prosocial behavior in Eastern and Western countries: A meta-analytic review. Psychological Bulletin, 136(2), 151-173. doi: 10.1037/a0018251

Baek, Y.-M., Lee, J.-M., Kim, K.-S. (2013). A Study on Smart Phone Use Condition of Infants and Toddlers. International Journal of Smart House, 7(6), 123-132. doi:10.14257/ijsh.2013.7.6.12

Bandura, A. (1977). Social learning theory. Englewood Cliffs, NJ: Prentice Hall. doi: 10.1177/105960117700200317

Blum-Ross, A., \& Livingstone, S. (2016). Families and screen time: Current advice and emerging research. London: Media Policy Project, London School of Economics and Political Science. Retrieved from: http://eprints.lse. ac.uk/66927/1/Policy\%20Brief\%2017-\%20Families\%20\%20Screen\%20Time.pdf

Blum-Ross, A. \& Livingstone, S. (2016). Families and Screen Time: Current Advice and Emerging Research. In S. P. Gangadharan (Ed.), Media Policy Project Policy Brief Series (Vol. 17). London: London School of Economics. Retrieved from: http://eprints.1se.ac.uk/66927/1/Policy\%20Brief\%2017-\%20Families\%20\%20Screen\%20Time.pdf

Braun, V., \& Clarke, V. (2006). Using thematic analysis in psychology. Qualitative Research in Psychology, 3(2), 77-101. doi: 10.1191/1478088706qp063oa

Burke, A., \& Marsh, J. (2013). Children's Virtual Play Worlds: Culture, Learning, and Participation. New York: Peter Lang. doi: 10.3726/978-1-4539-1069-6

Chakroff, J., \& Nathanson, A. I. (2008). Parent and school interventions: Mediation and media literacy. In S. L. Calvert \& B. J. Wilson (Ed.), The handbook of children, media, and development (pp. 552-576). West Sussex, England: Blackwell.

Chaudron S., Beutel M. E., Černikova M., Donoso Navarette V., Dreier M., Fletcher-Watson B., Heikkilä A-S., Kontríková V., Korkeamäki R-L., Livingstone S., Marsh J., Mascheroni G., Micheli M., Milesi D., Müller K. W., Myllylä-Nygård T., Niska M., Olkina O., Ottovordemgentschenfelde S., Plowman L., Ribbens W., Richardson J., Schaack C., Shlyapnikov V., Šmahel D., Soldatova G. and Wölfling K. (2015). Young Children (0-8) and digital technology: A qualitative exploratory study across seven countries. JRC 93239 / EUR 27052 / ISBN 978-92-7945023-5 / ISSN: 1831-9424. Retrieved from: http://publications.jrc.ec.europa.eu/repository/handle/JRC93239

Chassiakos, L., Radesky, J., Christakis, D., Moreno, M. \& Cross, C. (2016). Children and adolescents and digital media. Pediatrics, 138(5), 1-18. doi: 10.1542/peds.2016-2593

Common Sense Media. (2015). The Common Sense census: Media use by tweens and teens. San Francisco, CA: Common Sense Media.

Croatian Bureau for Statistics (2018). Usage of the information and communication technologies (ICT) in households and by individuals. Retrieved from https://www.dzs.hr/

Domoff, S. E., Harrison, K., Gearhardt, A. N., Gentile, D. A., Lumeng, J. C., \& Miller, A. L. (2017). Development and Validation of the Problematic Media Use Measure: A Parent Report Measure of Screen Media "Addiction" in Children. Psychology of Popular Media Culture, 8(1), 2-11. doi: 10.1037/ppm0000163

Eurostat (2018). Living conditions in Europe. Retrieved from: https://ec.europa.eu/eurostat/documents/3217494/9079352/ KS-DZ-18-001-EN-N.pdf/884f6fec-2450-430a-b68d-f12c3012f4d0

Felt, L. J., Robb, M. B. (2016). Technology Addiction: Concern, Controversy and Finding a Balance. San Francisco, CA: Common Sense Media.

Galpin, A., \& Taylor, G. (2018). Changing behavior: Children, adolescents and screen use. The British Psychological Society, 1-6. Retrieved from: https://www.bps.org.uk/sites/bps.org.uk/files/Policy/Policy\%20-20Files/Changing\%20 behaviour\%20-\%20children,\%20adolescents, $\% 20$ and $\% 20$ screen $\% 20$ use.pdf 
Hrvatska revija za rehabilitacijska istraživanja 2019, Vol 55, br. 2, str. 1-13

Genc, Z. (2014). Parent's Perceptions about the Mobile Technology Use of Preschool Aged Children. ProcediaSocial and Behavioral Sciences, 146, 55-60. doi: 10.1016/j.sbspro.2014.08.086

Goodman, I. F. (1983). Television's Role in Family Interaction - A Family Systems Perspective. Journal of Family Issues, 4(2), 405-424. doi: 10.1177/019251383004002009

Gentile, D. A., \& Walsh, D. A. (2002). A normative study of family media habits. Journal of Applied Developmental Psychology, 23(2), 157-178. doi: 10.1016/S0193-3973(02)00102-8

Greitemeyer, T. (2011). Effects of Prosocial Media on Social Behavior - When and Why Does Media Exposure Affect Helping and Aggression? Current Directions in Psychological Science, 20(4), 251-255. doi: $10.1177 / 0963721411415229$

Hanna, L. E. (2016). Parent Perception of Technology on Children's Language Development. Honors Theses and Capstones. Retrieved from: http://scholars.unh.edu/honors/297

Helsper, E. J., Kalmus, V., Hasebrink, U., Sagvari, B. \& de Haan, J. (2013) Country classification: opportunities, risks, harm and parental mediation. EU Kids Online, The London School of Economics and Political Science, London. Retrieved from: http://eprints.lse.ac.uk/52023

Hatzigianni, M., \& Margetts, K. (2014). Parents' beliefs and evaluations of young children's computer use. Australasian Journal of Early Childhood, 39(4), 114-122. doi:10.1177/183693911403900415

Jordan, A. B., Hersey, J. C, McDivitt, J. A., \& Heitzler, C. D. (2006). Reducing children's television-viewing time: A qualitative study of parents and their children. Pediatrics, 118(5), 1303-1310. doi: 10.1542/peds.2006-0732

Kalmus, V., \& Roosalu, T. (2012). Institutional filters on children's internet use: An additional explanation of crossnational differences in parental mediation. E-youth: Balancing between opportunities and risks, 234-250.

KFF (Keiser Family Foundation). (2004). The Role of Media in Childhood Obesity. Retrieved from: https://www.kff. org/other/issue-brief/the-role-of-media-in-childhood-obesity/

Kotrla Topić, M., \& Perković Kovačević, M. (2017). The Role of Digital Technology in the Lives of Young Children in Croatia. In: I. Burić (Ed), Book of selected proceedings of 20th Psychology Days in Zadar (pp. 93-101). Zadar: University of Zadar - Department of Psychology.

Kucirkova, N. (2011). Digitalized early years - Where next? New Voices, 24(12), 938-940. Retrieved from: https:// thepsychologist.bps.org.uk/volume-24/edition-12/new-voices-digitalised-early-years-where-next

Li, X., Atkins, M.S., Stanton, B. (2006). Effects of home and school computer use on school readiness and cognitive development among head start children: a randomized controlled pilot trial. Merrill Palmer Quarterly, 52, 239-263. doi: 10.1353/mpq.2006.0010.

Livingstone, S., Van Couvering, E. \& Thumim, N. (2005). Adult media literacy: A review of the research literature. London: Ofcom.

Livingstone, S., Gorzig, A., \&Olafsson, K. (2011). Disadvantaged children and online risk. EU Kids Online network, London, UK. Retrieved from: http://eprints.lse.ac.uk/39385/

Livingstone, S., G., Mascheroni, M., Dreier, S., Chaudron, K.,\& Lagae, K. (2015). How parents of young children manage digital devices at home: The role of income, education and parental style. Retrieved from: http://eprints. lse.ac.uk/63378/

Livingstone, S., Ólafsson, K., Helsper, E.J., Lupiáńez-Villanueva, F., Veltri, G.A., \& Frans Folkvord, F. (2017). Maximizing Opportunities and Minimizing Risks for Children Online: The Role of Digital Skills in Emerging Strategies of Parental Mediation. Journal of Communication, 67(1), 82-105. doi: 10.1111/jcom.12277

Marshall, S. J., Biddle, S. J., Gorely, T., Cameron, N., Murdey, I. (2004). Relationships between media use, body fatness and physical activity in children and youth: A metaanalysis. International Journal of Obesity, 28(10), 1238-1246. doi: 10.1038/sj.ijo.0802706 
McCarrick, K., \& Li, X. (2007). Buried treasure: The impact of computer use on young children's social, cognitive, language development and motivation. AACE Journal, 15(1), 73-95. Retrieved from: https://www.google.co.in/ url? $\mathrm{sa}=\mathrm{t} \& \mathrm{rct}=\mathrm{j} \& \mathrm{q}=\& \mathrm{esrc}=\mathrm{s} \&$ source $=$ web $\& \mathrm{~cd}=1 \& \mathrm{ved}=0$ ahUKEwip94_r0p_LAhWLI44KHTI2DtcQFggcMAA \&url=https\%3A\%2F\%2Fwww.editlib.org\%2Fp\%2F 19982\%2Farticle_19982.pdf\&usg=AFQjCNH6xYrkIyjoY bpdrIbx3ceys67BDg\&cad=rja

McPake, J., Plowman, L., \& Stephen, C. (2013). Pre-school children creating and communicating with digital technologies in the home. British Journal of Educational Technology, 44(3), 421-431. doi:10.1111/j.14678535.2012.01323.x

Meirick, P. C., Sims, J. D., Gilchrist, E. S., Croucher, S. M. (2009). Parents' perceptions of education and materialism as media effects on their own and other children. Mass Communication and Society, 12, 217-237. doi: 10.1080/15205430802439554

Mikelić Preradović, N., Lešin G., \& Šagud, M. (2016). Investigating Parent's Attitudes towards Digital Technology Use in Early Childhood: A Case Study from Croatia. Informatics in Education, 15(1), 127-146. doi: 10.15388/ infedu.2016.07

Nathanson, A. I., Eveland, W. P. J., Park, H-S., \& Paul, B. (2002). Perceived media influence and efficacy as predictors of caregivers' protective behaviors. Journal of Broadcasting \& Electronic Media, 46(3), 985-1410. doi: 10.1207/ s15506878jobem4603_5

Nevski, E. \& Siibak, A. (2016). The role of parents and parental mediation on 0-3-year olds' digital play with smart devices: Estonian parents' attitudes and practices. Early Years An International Research Journal, 36(3), 227-241. doi:10.1080/09575146.2016.1161601

Nikken, P., \& Jansz, J. (2014). Developing Scales to Measure Parental Mediation of Young Children's Internet Use. Learning, Media and Technology, 39(2), 250-266. doi: 10.1080/17439884.2013.782038

Nikken, P. \& Schols, M. (2015). How and Why Parents Guide the Media Use of Young Children. Journal of Child and Family Studies, 24, 3423-3435. doi: 10.1007/s10826-015-0144-4

O'Hara, M. (2011). Young children's ICT experiences in the home: Some parental perspectives. Journal of Early Childhood Research, 9(3), 220-231. doi: 10.1177/1476718X10389145

Ólafsson, K., Livingstone, S., \& Haddon, L. (2013). Children's Use of Online Technologies in Europe: A Review of the European Evidence Database. London School of Economics and Political Science and EU Kids Online, London. Retrieved from:

http://www2.lse.ac.uk/media@lse/research/EUKidsOnline/EU\%20Kids\%20Online\%20reports.aspx.

Ortiz, R. W., Green, T., \& Lim, H. (2011). Families and home computer use: Exploring parent perceptions of the importance of current technology. Urban Education, 46(2), 202-215. doi: 10.1177/0042085910377433

Padilla-Walker, L. M. (2006). "Peers I can monitor, it's media that really worries me!” Parental cognitions as predictors of proactive parental strategy choice. Journal of Adolescent Research, 21(1), 56-82. doi: 10.1177/0743558405282723

Plowman, L., \& Stephen, C. (2003). A "benign addition" Research on ICT and pre-school children. Journal of Computer Assisted Learning, 19(2), 149-164. doi: 10.1046/j.0266-4909.2003.00016.x

Plowman, L., McPake, J., \& Stephen, C. (2010). The technologisation of childhood? Young children and technology in the home. Children \& Society, 24(1), 63-74. doi:10.1111/j.1099-0860.2008.00180.x

Plowman L., Stevenson O., Stephen C., \& McPake, J. (2012). Preschool children's learning with technology at home. Computers \& Education, 59(1), 30-37. doi: 10.1016/j.compedu.2011.11.014

Poli, R. (2017). Internet addiction update: diagnostic criteria, assessment and prevalence. Neuropsychiatry, 7(1), 4-8. doi:10.4172/Neuropsychiatry.1000171

Rasmussen, E. E., White, S. R., King, A. J., Holiday, S., \& Densley, R. L. (2016). Predicting parental mediation behaviors: The direct and indirect influence of parents' critical thinking about media and attitudes about parentchild interactions. Journal of Media Literacy Education, 8(2), 1-21. doi: 10.23860/JMLE-2016-08-02-01 
Rideout, V., Vandewater, E., \& Wartella, E. (2003). Zero to Six: Electronic Media in the Lives of Infants, Toddlers, and Preschoolers. Menlo Park, CA: Kaiser Family Foundation. Retrieved from: https://www.kff.org/other/report/ zero-to-six-electronic-media-in-the/

Rideout, V. (2017). The Common-Sense census: Media use by kids age zero to eight. San Francisco, CA: Common Sense Media. Retrieved from: https://www.commonsensemedia.org/research/the-common-sense-census-mediause-by-kids-age-zero-to-eight-2017

Roberts, D. \& Foehr, U. (2004). Kids and Media in America. Cambridge: Cambridge University Press.

Schlembach, S., \& Johnson, M.L. (2014). Parents' beliefs, Attitudes and behaviors concerning Their Young Children's Screen Media Use. Dialog, 17(2), 95-104.

Sanders, W., Parent, J., Forehand, R., Sullivan, A. D. W., \& Jones, D. J. (2016). Parental perceptions of technology and technology-focused parenting: Associations with youth screen time. Journal of Applied Developmental Psychology, 44, 28-38. doi: 10.1016/j.appdev.2016.02.005

Swing, E. L., Gentile, D. A., Anderson, C. A., \& Walsh, D. A. (2010). Television and Video Game Exposure and the Development of Attention Problems. Pediatrics. Retrieved from: www.pediatrics.org/cgi/doi/10.1542/peds.20091508

Tokes, G. (2016). Digital practices in everyday lives of 4 to 6 years old Romanian children. Journal of Comparative Research in Anthropology and Sociology, 7(2), 93-110. Retrieved from: http://compaso.eu/wpd/wp-content/ uploads/2017/02/Compaso2016-72-Tokes.pdf

Vaala, S., \& Hornik, R. (2014). Predicting US infants' and toddlers' TV/video viewing rates: Mothers' cognitions and structural life circumstances. Journal of Children and Media, 8(2), 163-182. doi: 10.1080/17482798.2013.824494

Vandewater, E. A., Rideout, V. J., Wartella, E. A., Huang, X., Lee, J. H., \& Shim, M. S. (2007). Digital childhood: electronic media use among infants, toddlers, and preschoolers. Pediatrics, 119, 1006-1015. doi: 10.1542/ peds.2006-1804

Vittrup, B. (2009.) What US parents don't know about their children's television use: discrepancies between parents' and children's reports. Journal of Children and Media, 3(1), 51-67. doi: 10.1080/17482790802576972

Vittrup, B., Snider, S., Rose, K. K., \& Rippy, J. (2016). Parental perceptions of the role of media and technology in their young children's lives. Journal of Early Childhood Research, 14(1), 43-54. doi: 10.1177/1476718X14523749

\section{ISTRAŽIVANJE RODITELJSKE PERCEPCIJE DIGITALNE TEHNOLOGIJE KOD DJECE PREDŠKOLSKE DOBI U DVIJE TOČKE MJERENJA}

Sažetak: Kako bismo istražili kakva je percepcija digitalne tehnologije od strane roditelja predškolske djece u Hrvatskoj, kakva je roditeljska medijacija dječjih interakcija s digitalnim uređajima, proveli smo kvalitativno istraživanje s dva mjerenja. U prvom istraživanju provedeno je pet dubinskih intervjua s petero roditelja i njihove djece u dobi od 6 i 7 godina na temu upotrebe digitalne tehnologije. U ponovljenom istraživanju, godinu i pol dana kasnije, dubinskim intervjuima s istih pet obitelji, ispitali smo je li i u kojoj mjeri došlo do promjena u navedenim varijablama. Rezultati pokazuju kako roditelji digitalne medije često smatraju važnim za kognitivni i emocionalni razvoj djece, no istovremeno se pribojavaju mogućih negativnih posljedica njihova korištenja. Najčešće primjenjuju restriktivne oblike medijacije. Godinu i pol dana kasnije roditelji sve jasnije ističu kako im je potrebna potpora i daljnja edukacija o tome kako moderirati dječje interakcije s digitalnom tehnologijom.

Ključne riječi: digitalna tehnologija, roditeljska percepcija, medijacijske strategije, predškolska dob 